\title{
DIETA DEL BOYERO NEGRO CACICUS SOLITARIUS (AVES: ICTERIDAE) EN EL VALLE DE INUNDACIÓN DEL RÍO PARANÁ, ARGENTINA
}

\author{
Rossetti, M. A. ${ }^{1}$, Alessio, V. ${ }^{2}$, \\ BeltZer, A. H. ${ }^{3}$ \& DíAZ, H. F. ${ }^{4}$
}

\begin{abstract}
RESUMEN
El objetivo fue investigar la alimentación de Cacicus solitarius en el valle de inundación del río Paraná. Se da a conocer el análisis cuali-cuantitativo de ocho contenidos estomacales, pertenecientes a muestreos efectuados entre 1981-1985. El valor medio de diversidad trófica (H) fue 1,13 y la diversidad trófica acumulada (Hk) fue 2,49. Los resultados indican una dieta con 16 entidades taxonómicas destacándose semillas de Compuestas y algunas trepadoras apoyantes, Himenópteros, Formícidos, Coleópteros, Ortópteros y Lepidópteros.

Los valores para el índice de importancia relativa (IRI) indican una dieta omnívora en la que los insectos con los Coleoptera y las semillas constituyen las categorías básicas, en tanto que los Himenóptera (Formicidae) y los Orthoptera las categorías secundarias, siendo ingestas accesorias los Lepidoptera.

La mayor amplitud del nicho trófico se registró para el invierno. La eficiencia alimentaria fue del 96,6\%, visualizándose una mayor actividad en las primeras horas del día.

Cacicus solitarius posee una dieta omnívora, incluyéndoselo en el gremio de las aves omnívoras con picoteo y espigueo básicamente en follaje.

Palabras claves: Aves, Cacicus solitarius, dieta, río Paraná.
\end{abstract}

\section{SUMMARY}

Feeding of the solitary cacique cacicus solitarius (Birds: Icteridae) in the floodplain of the paraná river, argentina

The objective was research the feeding of Cacicus solitarius in the floodplain of Paraná River. We show the quali-quantitative analysis of eight stomach contents, belongings to individuals captured between 1981 and 1985 . The average of trophic diversity was 1.13 and the accumulated trophic

1.- Facultad de Ciencia y Tecnología (UADER), Estudiante de la Maestría en Ecología. Pasante en el INALI. e-mail: marialerossetti@yahoo.com.ar

2.- Tesista en el INALI, Facultad de Humanidades y Ciencias, Universidad Nacional del Litoral (UNL).

e-mail: vialessio@yahoo.com.ar

3.- Investigador del CONICET. Instituto Nacional de Limnología -INALI (CONICET-UNL). José Maciá 1933, (3016) Santo Tomé (Santa Fe), e-mail: inali@ceride.gov.ar

4.- Estudiante Biología, Facultad de Ciencia y Tecnología (UADER), Paraná. Lugar de trabajo: Instituto Nacional de Limnología (INALI-CONICET).

Manuscrito recibido el 17 de marzo de 2003 y aceptado para su publicación el 29 de marzo de 2004. 
diversity was 2.49. The results indicate a diet with 16 taxonomic entities standing out seeds of Compositae and some climbing, Hymenoptera, Coleoptera, Orthoptera and Lepidoptera. The values for the relative importance index (IRI) show an omnivorous diet where the insects with the Coleoptera and the seeds are the basics categories, while the Hymenoptera (Formicidae) and Orthoptera are the secondary categories, being accessories ingestion the Lepidoptera.

The greatest amplitude for the trophic niche was registered for the winter. La alimentary efficiency was $96.6 \%$, being observed the greatest activity in the first day hours.

Cacicus solitarius has an omnivorous diet, being included in the omnivorous birds guild with pick and gleaning in foliage and ground.

Key words: Birds, Cacicus solitarius, feeding, Paraná River. 